Заїка Свген Валентинович

(C) Заїка Є. В., 2017

Харківський національний університет імені В. Н. Каразіна

\title{
ТРЕНІНГ ГНУЧКОСТІ ТА ШВИДКОСТІ ПРОСТОРОВОГО МИСЛЕННЯ І РУХОВИХ КООРДИНАЦІЙ (ДЛЯ ШКОЛЯРІВ І СТУДЕНТІВ)
}

В статті мова йдеться про розвиток $і$ вдосконалення просторового мислення. Розглядається комплекс вправ, спрямованих на формування образно-просторового мислення завдяки рухам власного тіла, зокрема ті, щзо виконуються руками. Описані правила проведення вправ та самі вправи.

Ключові слова: просторове мислення, рухові координації, ігровий тренінг мислення.

Проблема, їі зв'язок із важливими науковими чи практичними завданнями. Просторове мислення - важливий елемент розумової діяльності людини, важлива складова структури інтелекту. На жаль, іiі розвитку й удосконалюванню, на відміну від словесно-логічного мислення, приділяється недостатньо уваги. Істотним аспектом просторового мислення виступає координація рухів, що виконуються руками за строго визначеними правилами.

Аналіз публікацій (виділення невирішених проблем). У численних варіантах ігрового тренінгу мислення розглядаються різні ігри та вправи, спрямовані на розвиток в основному словеснологічного мислення $[1 ; 2]$, що ж стосується мислення образного i особливо образно-просторового, то таких вправ явно недостатньо. Істотною частиною просторового мислення і побудови власних дій в просторі $\epsilon$ координація рухів власними руками за строго заданими правилами, причому ці координації повинні здійснюватися швидко і перебудовуватися легко.

Ціль статті - пропонується ігровий тренінг, спрямований на розвиток гнучкості та швидкості просторового мислення та рухових координацій руками.

Виклад основного матеріалу, обгрунтування результатів дослідження. Перелічено основні вправи, які включено до запропонованого комплексу. Складається з наступного розділу: рухові вправи для розвитку просторово мислення руками.

1. Ведучий (викладач) стає спиною до гравців і в повільному темпі робить зміну зазначених вище напрямків рук. Завдання гравців точно повторювати рухи ведучого. Наприклад, із вихідного положення 


\section{Збірник наукових статей}

(руки вниз) ведучий піднімає ліву руку убік, праву вгору і на 3-4 секунди фіксує їхнє положення (діти копіюють); потім ліву руку заводить назад за спину, а праву відводять уперед - убік (діти копіюють) тощо.

Поступово ведучий скорочує паузи і прискорює темп зміни положень рук; діти намагаються повторювати за ним і при цьому не заплутатися у копіюванні рухів. Один із гравців (по черзі) не виконує рухи, а стежить за правильністю їхнього виконання іншими гравцями, за необхідності вказує на помилки.

2. Ведучий повертається обличчям до гравців. При такому взаєморозташуванні ведучого і гравців можливі два принципово різних способи відтворення гравцями рухів ведучого: за зовнішніми орієнтирами і за схемою тіла. Гравцям докладно пояснюється сутність кожного із двох способів відтворення рухів.

Відтворення за зовнішніми орієнтирами передбачає напрямок правої руки в той же бік, у який спрямована права рука ведучого. Це означає: так само на схід (на північ, на захід, на південь) чи так само до тієї стіни кімнати, де розташовані вікна (двері, дошка тощо). При цьому важлива вказівка на ті зовнішні орієнтири (предмети, стіни кімнати, частини світу), до яких направляє руку ведучий, безвідносно до того, яке положення рука займає щодо тіла.

Наприклад, якщо, стоячи до вас обличчям, ведучий відводить свою праву руку назад (щодо себе), вказуючи нею на ту стінку кімнати, що знаходиться в нього за спиною, але у вас перед очима. Ваша задача - вказати на той же напрямок, тобто простягнути руку до тієї ж стінки, що знаходиться перед вами, тому ви піднімаєте руку вперед. Аналогічно, якщо ведучий відвів руку вліво (відносно себе), то він тим самим указав на стінку праворуч від вас, тому ви повинні відвести руку вправо.

Відтворення рухів за схемою тіла означає що треба своїм тілом скопіювати положення тіла ведучого безвідносно до зовнішніх орієнтирів.

Наприклад, ведучий відвів праву руку назад (відносно себе). Ваша задача - надати своєму тілу такого ж положення, тобто відвести руку назад (при цьому не має ніякого значення, на яку стінку вона показує). Аналогічно, якщо ведучий відвів руку вліво (відносно себе), то ви повинні відвести свою руку вліво відносно себе, не звертаючи уваги на те, до якої стінки вона спрямована.

Якщо рух у горизонтальній площині (назад, уліво - вправо і проміжні між ними) при двох способах відтворення рухів завжди протилежні, то рухи у вертикальній площині (униз) завжди збігаються.

Після ознайомлення гравців із цими двома способами відтворення рухів починається тренування за кожним із них. При 
цьому ведучий називає спосіб, наприклад, «за схемою тіла». I далі протягом 1-3 хвилин пропонує гравцям відтворювати різні положення рук, наприклад: а) праву - вгору, ліву - уперед; б) праву - уліво, ліву назад; в) праву - назад, ліву - вгору тощо. Потім ведучий називає новий спосіб: «за зовнішніми орієнтирами», і протягом 1-2 хвилин пропонує нову серію вправ, аналогічних зазначеній вище. У міру тренування необхідно все частіше змінювати спосіб відтворення (наприклад, через кожні 10-15 секунд) і задавати нові варіанти рухів у все більш швидкому темпі (аж до однієї позиції за кожні 2-3 секунди!).

3. Ведучий повертається до гравців почергово то правим, то лівим боком i, знаходячись у такому положенні й періодично змінюючи способи відтворення рухів, задає гравцям різні варіанти положень рук.

Наприклад, ведучий став до гравців правим боком i назвав спосіб: «за зовнішніми орієнтирами», далі відвів праву руку назад, а ліву - вправо (відносно себе). При цьому правою рукою він указав на стінку, що знаходиться від гравця ліворуч! Тому вони праву руку повинні направити вліво (відносно себе), щоб вона вказувала на ту ж стінку! А ліва рука його вказує на стінку, що знаходиться прямо перед гравцями, тому вони повинні направляти ліву руку вперед!

Після серії подібних рухів ведучий задає новий спосіб: «за схемою тіла» i, наприклад, піднімає праву руку нагору, а ліву - уперед (відносно себе). Гравці повинні відтворити ту ж конфігурацію тіла (не звертаючи уваги на стінки, до яких спрямовані руки ведучого). Поступово час на кожен спосіб руху скорочується, у результаті чого гравцям доводиться все частіше перемикатися 3 одних орієнтирів на інші, й навпаки.

4. Ведучий стоїть обличчям до гравців, орієнтуватися треба лише за схемою тіла. Однак, на відміну від завдань, описаних у пункті «2», гравцям слід своєю лівою рукою відтворювати положення правої руки ведучого щодо тіла, а своєю правою рукою - його лівої руки. Наприклад, у ведучого права рука витягнута вперед, ліва відведена вліво. Це значить, що гравець повинен свою ліву руку витягнути вперед, а праву відвести вправо. Таке відтворення фактично означає дзеркальне відображення рухів ведучого.

Варто звернути увагу гравців на те, що описаний тут дзеркальний спосіб відтворення рухів відрізняється від двох інших способів, вивчених раніше: за зовнішніми орієнтирами і за схемою тіла. Таким чином, тепер учень уже знає три способи відтворення рухів ведучого, що стоїть до нього обличчям.

5. Ведучий чергує всі три способи відтворень, відводячи на кожний по 20-30 секунд (і відповідно по 4-6 позицій). Наприклад, спершу говорить: «за схемою тіла» і показує одне за одним 3-4 
положення рук; потім говорить: «дзеркально» і показує 4-5 положень рук; потім говорить: «за зовнішніми орієнтирами» тощо. Від гравців потрібно швидко перемикатися 3 одного способу на інший i точне копіювання рухів відповідно до заданого способу.

6. Ця вправа $є$ ускладненим варіантом попередньої. Тут перед кожним показом нової позиції ведучий називає спосіб копіювання; кожній черговій позиції відповідає новий спосіб; їхній вибір здійснюється випадково. Наприклад: «за схемою тіла» позиція: права рука - назад, ліва - уліво; потім: «за зовнішніми орієнтирами»: права рука - вгору, ліва - вправо через груди; потім: «дзеркально»: права рука - назад, ліва - вгору.

7. Стоячи обличчям до гравців, ведучий задає одну за іншою позиції, а гравці повинні їх відтворювати. Спосіб відтворення увесь час міняється, а правило цієї зміни задається заздалегідь. Наприклад, говориться: першу позицію копіюйте за принципом «дзеркало», другу - «схема тіла». Третю - «зовнішні орієнтири» і далі чергуйте способи в тому ж порядку; тут уже ведучий не називає щораз спосіб, його відслідковують самі гравці. Інші, більш складні варіанти чергувань способів: а) 2 «схема тіла», 1 «дзеркально», 3 «зовнішні орієнтири» і т. д; б) 3 «схема тіла», 1 «дзеркально», 2 «зовнішні орієнтири»; 1 «дзеркально» і т. д; в) «зовнішні орієнтири» - «дзеркально» - 3 «схема тіла» та ін.

8. Задаються різні способи копіювання рухів лівої і правої руки ведучого. Наприклад, положення лівої руки ведучого потрібно копіювати способом «схема тіла», правої його руки способом «зовнішні орієнтири». Так, якщо ведучий, наприклад, простягнув обидві руки уперед, слід ліву простягнути вперед, а праву - відвести назад! Періодично вводяться нові правила (наприклад, ліву дзеркально, праву - за схемою тіла). Спочатку тренування на кожне правило приділяється по 2-3 хвилини, потім час скорочується до 3040 секунд, що бажає від дітей швидкого переключення 3 одного правила на інше.

9. Виконання вправ 2-8 ускладнюється введенням додаткового правила: при визначеній, заздалегідь обговореній умові кисті обох рук (чи тільки лівої чи правої) треба стискати в кулаки, (в інших випадках вони повинні бути виправлені).

Висновки, перспективи. Запропоновано та описано оригінальний комплекс вправ, спрямований на розвиток у школярів i студентів просторового мислення та рухових координацій руками. У подальшому планується розробити аналогічний комплекс для виконання вправ ногами, а також рухами голови та тулуба. 


\section{Література}

1. Заїка Є. В. Ігровий тренінг пізнавальних процесів учнів : ігри та вправи : навчальний посібник / Є. В. Заїка. - Х. : ХНУ імені В. Н. Каразіна, 2013. - 256 с.

2. Заїка Є. В. Шляхи оптимізації пізнавальної діяльності студентів та школярів : навчальний посібник / Є. В. Заїка, І. О. Зуєв. Х. : ХНУ імені В. Н. Каразіна, 2013 - 184 с.

Евгений Заика. Тренинг гибкости и быстроты пространственного мышления и двигательных координаций (для школьников и студентов).

B статье речь идет о развитии и совершенствовании пространственного мышления. Рассматривается комплекс упражнений, направленных на формирование образнопространственного мышления благодаря движениям собственного тела, в частности те, что выполняются руками. Описаны правила проведения упражнений и сами упражнения.

Ключевые слова: пространственное мылиление, двигательные координации, игровой тренинг мышления.

Yevgen Zaika. Training of flexibility and quick spatial thinking and motor coordination (for students of school and university).

This article is about development and improvement of the spatial thinking. There is a complex of exercises is being considered in this article aimed at formation of the image-spatial thinking thanks to movement own body, in particularly arm's movements. Describes the rules for conduction of exercises.

Keywords: spatial thinking, motor coordination, game thinking training.

Стаття надійшла до редакційної колегії 11.05.2017

УДК 159.9.072.59:159.938]:37.091.212

(C) Заїка Є. В., 2017

Заїка Свген Валентинович

Харківський національний університет імені В. Н. Каразіна

\section{ТРЕНІНГ ВНУТРІШНЬОГО ПЛАНУ ДІЙ ТА САМОРЕГУЛЯЦІЯ МИСЛЕННЯ: ГЕОМЕТРИЧНІ ЗАВДАННЯ В ДЕКАРТОВІЙ СИСТЕМІ КООРДИНАТ (ДЛЯ ШКОЛЯРІВ І СТУДЕНТІВ)}

Запропонована та описана система ігрового тренінгу внутрішнього плану дій та саморегуляиії мислення для школярів та студентів. Вправи полягають у виконанні завдань в проставленні та зчитуванні крапок у декартовій системі координат.

Ключові слова: мислення, внутрішній план дій, увага, саморегулячія мислення, декартова система координат. 